Gender, Family and Society 
Also by Faith Robertson Elliot

THE FAMILY: Change or Continuity? 


\section{Gender, Family and Society}

Faith Robertson Elliot

Consultant Editor: Jo Campling 
ISBN 978-0-333-52430-5

DOI 10.1007/978-1-349-24385-3

GENDER, FAMILY AND SOCIETY

Copyright $\odot 1996$ by Faith Robertson Elliot

Softcover reprint of the hardcover 1st edition 1996

All rights reserved. No part of this book may be used or reproduced in any manner whatsoever without written permission except in the case of brief quotations embodied in critical articles or reviews.

For information, address:

St. Martin's Press, Scholarly and Reference Division, 175 Fifth Avenue, New York, N.Y. 10010

First published in the United States of America in 1996

ISBN 978-0-312-12990-3 (cloth)

ISBN 978-0-312-12991-0 (pbk)

Library of Congress Cataloging-in-Publication Data

Elliot, Faith Robertson.

Gender, family, and society / Faith Robertson Elliot.

p. $\mathrm{cm}$.

Includes bibliographical references and index.

ISBN 978-0-312-12990-3 (cloth). — ISBN 978-0-312-12991-0 (pbk.)

1. Family. 2. Family-Great Britain. 3. Sex role. 4. Sex role-Great Britain. I. Title.

HQ518.E433 1996

$306.85-\mathrm{dc} 20$

95-36939

CIP 
For my students 


\section{Contents}

List of Tables and Figures $\quad$ x

Acknowledgements xiii

1 Introduction 1

1.1 The relationship revolution 5

The mid-twentieth century Western family 6

The birth of permissiveness $\quad 9$

Contemporary change in family patterns 12

How much change? 34

2 Ethnic Differentiation, Gender and Family Life 40

2.1 The evolution of Afro-Caribbean and Asian gender and family structures in Britain $\quad 40$

Afro-Caribbean gender and family structures 42

Asian gender and family structures $\quad 48$

$\begin{array}{ll}\text { Summary } & 57\end{array}$

2.2 The discourses of 'race' and ethnicity 58

'Racist' and 'nationalist' discourses 58

'Black' radical and anti-racist perspectives 62

'Black' feminist perspectives $\quad 65$

Ethnicity perspectives $\quad 68$

Marxist and marxist-feminist approaches $\quad 70$

$\begin{array}{ll}\text { Summary } & 73\end{array}$

3 Economic Restructuring and Unemployment:

a Crisis for Masculinity?

3.1 Unemployment trends and patterns 76

3.2 Unemployment and family life $\quad 81$

Married men, unemployment and family life 83

Women, unemployment and family life $\quad 92$

Coming of age unemployed $\quad 96$

3.3 The underclass debate 103 
4 Population Ageing and the 'Problem' of Care

4.1 The construction of 'old age' as a social problem

The demographic ageing of populations

Images of ageing

The relationship of older people to the economy 119

4.2 Family life and eldercare

The caring task

125

The normative context of caring

Patterns of care

The caring experience

The challenge to ageism

Summary

5 Violence and Sexual Abuse in Family Life

5.1 Conceptualising 'violence' in family life

Summary

5.2 Levels of violence

Parental violence

152

The sexual abuse of children

Violence and sexual coercion in sexual partnerships

Summary

5.3 Perspectives on familial violence/sexual abuse

Psychopathological perspectives

Non-feminist sociological perspectives

Feminist perspectives

In conclusion

6.1 Epidemiological considerations 184

6.2 The sexual politics of AIDS 189

The conflict between the 'old' and 'new' moralities 190

Representations of AIDS in the discourses of moral conservativism

Representations of AIDS in gay discourses

Representations of AIDS in feminist discourses $\quad 197$

6.3 The end of the sexual revolution? 199

Methodological problems 
Contents ix

AIDS and change in gay lifestyles

201

Heterosexual relations in the shadow of AIDS

207

Summary

212

7 Epilogue

214

Bibliography

221

Author Index

250

Subject Index

256 


\section{List of Tables and Figures}

\section{Tables}

1.1 Cohabitation in northwest Europe, Britain and the USA 15

1.2 Proportion ever married and mean age at first marriage for women in selected northwest European countries, 1988

1.3 Cohabitation patterns among women aged 18-49 in Britain

1.4 Attitudes to unmarried cohabitation in selected Western countries

1.5 Conceptions by marital status and outcome, England and Wales, 1971 and 1991

1.6 Proportion of families with children under 18 , headed by a lone parent, in selected northwest European countries, 1989, and in the USA, 1990

1.7 Women aged 16-59 in employment by age of youngest child, Great Britain, 1973-92

1.8 Attitudes towards women with dependent children working

2.1 Marital status by ethnic group, Great Britain, 1986-8

2.2 One-parent families with dependent children, as a proportion of all families' by ethnic group, Great Britain, 1987-9

2.3 Labour force participation rates of women, aged 16-59, by ethnic group, Great Britain, 1988-90

3.1 Unemployment rates in selected industrial countries, 1976-92

3.2 Unemployment rates by socio-economic group and sex, Great Britain, 1992

3.3 Unemployment rates by sex and age, United Kingdom, 1993

3.4 Duration of unemployment by sex and age, United Kingdom, 1993

4.1 Life expectancy in the United Kingdom, 1901-91

4.2 Numbers and proportions of older people in the United Kingdom, 1901-90 
4.3 Marital status of women and men over 65 in Great Britain, 1992

4.4 Life expectancies and proportions of the population aged 65 and over in selected industrial societies, 1991

4.5 Disability level of older women and men by age, Great Britain, 1985

4.6 Poverty rates among people over 65 in selected industrial countries

5.1 Parent-to-child violence in 1975 and 1985 in the USA 153

5.2 Experiences of sexually-abused children, British data 157

5.3 Experience of sexual abuse in childhood, San Fransisco data

5.4 Marital violence in the USA, 1975 and 1985

5.5 Prevalence of domestic violence among north London women

5.6 Prevalence of rape/attempted rape by relationship between victim and assailant

6.1 AIDS cases in the USA by exposure category as at June 1993

6.2 AIDS cases by sex and exposure category in the United Kingdom to 30 June 1992

6.3 Median number of male sexual partnerships of gay men over various time periods

6.4 Gay relationship types and durations 204

\section{Figures}

1.1 Live births outside marriage as a percentage of all births: international comparisons, 1960 and 199123

1.2 Real weekly earnings by sex, Great Britain, 1971-93 31

3.1 Unemployment by ethnicity, Great Britain, $1991 \quad 80$

4.1 Average hours of informal care provided by

(a) co-resident carers and (b) carers in a separate household by relationship between carer and cared for and by gender of carer

6.1 AIDS throughout the world, mid-1993 186

6.2 AIDS prevalence rates in the countries of the European Union, March 1992 
xii List of Tables and Figures

6.3 Proportion of homosexual men engaging in anal intercourse with men, 1987-91 


\section{Acknowledgements}

Pat Allatt, Sara Arber, Ken Blakemore, Jacqui Halson, Kathleen Kiernan and Jeffrey Weeks read early drafts of particular chapters of this book, while David Morgan and Nick Tilley read the penultimate draft of the whole. I am grateful to them all for their constructive and insightful comments, for their time and for their encouragement. I would also like to thank the staff of the Lanchester Library, Coventry University, and in particular Barbara Heaton and Geoffrey Stratford, for their exceptional helpfulness in my search for source materials for this book. Finally, I would like to thank Parbinder and Jaspreet Johal for all their assistance in obtaining books from, and returning books to, the Library on my behalf.

FAITH ROBERTSON ELLIOT

The author and publishers wish to thank those who have kindly given permission for the use of copyright material in charts and tables as follows: Cambridge University Press: Table 4.6; The Controller of Her Majesty's Stationery Office: Tables 1.2, 1.3, 1.5, 1.7, 2.1, 2.2, 3.1, 3.2, 3.3, 3.4, 4.1, 4.3 and 6.3 and Figures 1.1, 1.2 3.1, 6.2 and 6.3; Dartmouth Publishing Company Ltd: Tables 1.4 and 1.8; Guardian Newspapers Ltd: Figure 6.1; Indiana University Press: Table 5.6; Macmillan Press Ltd: Table 4.5; Middlesex University: Table 5.5; The National Council on Family Relations Minneapolis, MN 5421, USA: Tables 5.1 and 5.4; One Plus One: Table 1.1; The Office for Official Publications of the European Communities: Table 4.4: Elsevier Science Ltd: Table 5.2; The Policy Studies Institute: Table 2.3; Sage Publications: Figure 4.1; Taylor and Francis and the Controller of Her Majesty's Stationery Office: Table 6.4 